\title{
KESULITAN SISWA SMP DALAM PEMECAHAN MASALAH MATEMATIKA
}

\author{
Samsul Hadi \\ Program Studi Pendidikan Guru Sekolah Dasar, Institut Pendidikan Nusantara Global \\ Indonesia, 83511 \\ samsulhadi@nusantaraglobal.ac.id
}

\begin{abstract}
Abstrak. Pemecahan masalah merupakan salah satu kompetensi siswa yang dikembangkan pada kurikulum pembelajaran matematis dalam menghadapi setiap permasalahan baik di pembelajaran maupun di kehidupan sehari-hari. Fokus penelitian ini adalah memperoleh gambaran tentang kesulitan siswa dalam menyelesaikan masalah matematis di salah satu SMP Negeri di kabupaten Lombok Timur, NTB, Indonesia. Partisipan dalam penelitian ini adalah 29 siswa kelas VIII yang terdiri dari 14 siswa laki-laki dan 15 siswa perempuan pada tahun ajaran 2017/2018. Pemilihan partisipan dilakukan dengan purposifsampling. Metodologi penelitian yang digunakan adalah pendekatan kualitatif dengan menggunakan instrumen tes kemampuan pemecahan masalah, interview, observasi, dan studi dokumentasi. Hasil penelitian menunjukkan bahwa: (1) siswa tidak mampu memahami, mengidentifikasi, dan menafsirkan masalah dengan baik dan benar, (2) siswa tidak mampu membuat representasi masalah ke dalam model matematis, (3) siswa tidak mampu menjalankan strategi penyelesaian masalah yang telah dibuat dengan benar, (4) siswa tidak mampu melakukan perhitungan dengan benar dan teliti, (5) semua siswa tidak mampu membuat strategi alternatif penyelesaian masalah, dan (6) hampir semua siswa terindikasi kesulitan dalam aspek bahasa, seperempat siswa dalam aspek konsep/pemodelan, dan hampir separuh siswa dalam aspek terapan.
\end{abstract}

Kata kunci: Masalah Matematika, Kesulitan Siswa dalam Pemecahan Masalah, Representasi Masalah, Pemecahan Masalah Matematika

\begin{abstract}
Problem solving is one of the competencies of students developed in the mathematics learning curriculum in dealing with every problem both in learning and in everyday life. The focus of this research is to get a picture of the difficulty of students in solving mathematical problems in one of the State Junior High Schools in East Lombok district, NTB, Indonesia. Participants in this study were 29 students of class VIII consisting of 14 male students and 15 female students in the 2017/2018 school year. The selection of participants was done by purposive sampling. The research methodology used is a qualitative approach using test instruments for problem solving skills, interviews, observations, and documentation studies. The results showed that: (1) students were not able to understand, identify, and interpret problems properly, (2) students were not able to make representations of problems into mathematical models, (3) students were not able to carry out problem solving strategies that had been made correctly, (4) students are not able to do calculations correctly and thoroughly, (5) all students are not able to make alternative strategies for solving problems, and (6) almost all students are indicated difficulties in aspects of language, a quarter of students in aspects of concepts / modeling, and almost half the students in applied aspects.
\end{abstract}

Keywords: Mathematical Problems, Student Difficulties in Problem Solving, Problem Representation, Mathematical Problem Solving.

\section{PENDAHULUAN}

Siswa sebagai salah satu elemen masyarakat sekolah tentu dihadapkan pada suatu masalah baik sederhana maupun kompleks meskipun tidak semua dari masalah tersebut merupakan masalah matematis, 
namun tidak sedikit penyelesaian masalah tersebut membutuhkan ide atau gagasan pemikiran matematis. Dalam menghadapi masalah, tentu setiap orang memiliki pandangan atau cara yang berbeda-beda terhadap masalah tersebut. Hal ini berarti bahwa masalah yang sama belum tentu memiliki pandangan cara yang sama dalam menemukan jalan keluarnya. Dengan kata lain, situasi sederhana bisa jadi masalah yang kompleks bagi orang lain, akan tetapi di sisi lain bisa jadi situasi tersebut bukanlah suatu masalah. Salah satu faktor penyebabnya adalah setiap orang memiliki pengetahuan (prior knowledge) dan pengalaman yang berbeda-beda dalam memandang dan menyelesaikan suatu masalah. Begitu juga dengan siswa, di mana setiap siswa memiliki pengetahuan dan pengalaman yang berbedabeda dalam mengatasi masalah. Pemecahan masalah merupakan bagian dari kompetensi siswa yang ditekankan dalam kurikulum pembelajaran matematis. National Council of Teachers Mathematics (NCTM) (2000) mengemukakan bahwa beberapa komponen kompetensi siswa dalam mempelajari matematis, adalah (1) komunikasi matematis; (2) penalaran matematis; (3)pemecahan masalah matematis(4) koneksi matematis dan (5) representasi. Kompetensi matematis di atas, terutama pemecahan masalah berkaitan erat dengan empat pilar pembelajaran. Meskipun pemecahan masalah merupakan bagian dari kompetensi dan strategi dalam kurikulum pembelajaran namun kemampuan siswa dalam memecahkan masalah matematis masih terbilang rendah. Rendahnya kemampuan pemecahan masalah matematis siswa dapat dilihat pada hasil survey internasional The Third International Mathematics and Science Study (TIMSS) bahwa kemampuan siswa SMP kelas VIII Indonesia dalam menyelesaikan masalah matematis sangat lemah, namun relatif baik dalam menyelesaikan soal-soal tentang fakta dan prosedur(Mullis, Martin, Gonzales, Gregory, Garden, O’Connor, Krostowski, \& Smith, 2000; Herman, 2007).

Beberapa studi penelitian sebelumnya mengindikasikan kemampuan pemecahan masalah matematis siswa rendah, yaitu (1) Seifi, Haghverdi, \& Azizmohamadi (2012) bahwa siswa tidak mampu membuat representasi dan memahami dari masalah; (2) Salemeh \& Etchells (2016) bahwa dalam memecahkan masalah siswa kesulitan dalam memahami, menganalisis, dan menginterpretasikan masalah; (3) Jaenuri \& Riyadi (2017) bahwa ketika siswa memecahkan masalah, siswa tidak mampu membuat pemodelan matematis dari teks masalah; dan (4) Komarudin (2016) dan Sholihah \& Afriansyah (2017) bahwa ketidakmampuan siswa dalam menyelesaikan masalah matematis karena siswa seringkali kesulitan dalam memahami bacaan teks masalah, membuat strategi, dan melaksanakan strategi penyelesaian. Mengacu pada latar belakang masalah di atas, penulis tertarik melakukan sebuah studi kualitatif dengan tema' Kesulitan Siswa SMP dalam Pemecahan Masalah Matematis'. Rumusan masalah yang diajukan dalam penelitian ini adalah bagaimanakah kemampuan dan kesulitan siswa SMP kelas dalam pemecahan masalah matematis.

\section{TINJAUAN TEORI}

Syahlan (2017) mengatakan masalah dalam matematis adalah suatu pertanyaan yang menggugah sehingga tertantang untuk diselesaikan menggunakan segenap pengetahuan (konsep dan prinsip matematis) yang telah dimiliki sebagai dasar dalam membentuk konsep baru hingga dapat diselesaikan. Polya (1973) mengatakan bahwa masalah matematis ada dua jenis, yaitu (1) masalah menemukan (problem to find), masalah yang bertujuan menemukan, menentukan, atau memperoleh nilai suatu objek yang tidak dinyatakan dalam pertanyaan; dan (2) masalah membuktikan (problem to prove), masalah yang membutuhkan suatu prosedur dalam menunjukkan suatu pernyataan benar atau tidak.Krulik dan Rudnik (1995) pemecahan masalah adalah suatu usaha individu menggunakan pengetahuan, keterampilan dan pemahamannya untuk menemukan solusi dari suatu masalah. Dalam pemecahan masalah kesediaan siswa terlibat dalam suatu masalah 
sangat dibutuhkan dalam mencapai tujuan. Selain itu, siswa bisa mengembangkan diri menjadi pribadi yang konstruktif dan reflektif dalam menghadapi masalah. Hal ini disebabkan oleh kondisi kemampuan seseorang terlibat dalam proses berpikir kognitif untuk memahami dan mengatasi masalah tersebut (Csapó \& Funke, 2017). Dalam pemecahan masalah terdapat beberapa aktivitas yang dilakukan siswa dalam memperoleh suatu solusi dari permasalahan/masalah. Polya (1973) mengatakan bahwa ada empat tahapan aktivitas yang dilakukan pada pemecahan masalah, yaitu (1) memahami masalah (understand the problem), (2) merencanakan pemecahan (devise a plan), (3) Melaksanakan rencana (carry out theplan), dan (4) memeriksa kembali (looking back). Dalam artikel ini pemecahan masalah siswa dianalisis berdasarkan langkah-langkah Polya. Pada dasarnya tahapan aktivitas pemecahan masalah menurut Polya, Krulik \& Rudnik, dan Schoenfeld adalah tidak jauh berbeda dan hampir sama.Kesulitan siswa dalam belajar matematis khususnya dalam menyelesaikan masalah matematis pada dasarnya dipengaruhi oleh kendala-kendala yang dihadapi siswa saat belajar matematis baik dari konten, strategi, dan asesmen. Angateeah (2017) mengatakan bahwa dalam menyelesaikan masalah cerita siswa pada umumnya kesulitan dalam hal visualisasi dan representasi masalah ke bentuk model matematis. Jupri \& Drijvers (2016) bahwa siswa sering error dalam mengubah bentuk soal cerita ke dalam bentuk persamaan matematis, skema, dan diagram yang digunakan dalam menyelesaikan masalah matematis. Delacruz \& Lapinid (2014) mengatakan bahwa $40 \%$ siswa kesulitan dalam mengubah soal cerita ke model matematis dalam pemecahan masalah. Kesulitan siswa dalam mengerjakan soal cerita pada umumnya dikarenakan oleh kecerobohan, kekurangan pengetahuan, perubahan nilai, dan tidak familiar dengan bahasa yang digunakan dalam soal. Dalam artikel ini, penulis akan meninjau kesulitan siswa dalam ketigaaspek tersebut dengan beberapa rincian indikator yang termuat dalam aspek-aspek tersebut, yaitu: (a) Aspek bahasa, dalam aspek ini dibagi menjadi beberapa indikator yaitu (1) siswa tidak memahami makna kata kunci atau term-term /istilah matematis (simbol atau notasi) dalam soal, dan (2) siswa tidak dapat memahami makna per kalimat atau dapat memahami per kalimat namun secara keseluruhan siswa tidak memahami inti dari masalah dalam soal; (b) Aspek konsep atau pemodelan, dalam aspek ini dibagi menjadi beberapa indikator yaitu (1) siswa tidak mampu mentransformasikan soal ke dalam model matematis, dan (2) siswa tidak dapat menentukan rumus atau strategi yang digunakan dalam menyelesaikan masalah; (c) Aspek terapan, dalam aspek ini dapat dibagi menjadi dua indikator yang saling berhubungan yaitu (1) siswa tidak dapat menggunakan rumus atau strategi penyelesaian masalah, (2) siswa salah dalam proses perhitungan atau jawaban, dan (3) siswa tidak dapat melakukan verifikasi baik strategi, perhitungan, dan jawaban.

\section{METODE}

Penelitian dalam artikel ini menggunakan metode penelitian kualitatif. Fokus utama dalam penelitian adalah menganalisis kesulitan siswa dalam menyelesaikan masalah matematis. Lokasi penelitian adalah salah satu SMP Negeri di kabupaten Lombok Timur, NTB. Partisipan dalam penelitian ini adalah 29 siswa kelas VIII yang terdiri dari 14 siswa laki-laki dan 15 siswa perempuan pada tahun ajaran 2017/2018. Pemilihan partisipan dilakukan dengan purposive sampling. Pengumpulan data dilakukan dengan instrumen tes kemampuan pemecahan masalah, interview, observasi non partisipan, dan studi dokumentasi. Tespemecahan masalah matematis terdiri dari tes pilihan ganda sebanyak 12 soal dan tes uraian yang terdiri atas 5 soal. Tes pilihan ganda diberikan dalam mendiagnosa kesulitan-kesulitan apa saja yang dialami siswa dalam menyelesaikan masalah matematis. Tes uraian diberikan dalam mengetahui kemampuan pemecahan masalah matematis siswa secara kesuluruhan. Adapun interview, observasi, dan studi dokumentasi dilakukan penulis dalam mengkonfirmasi dan 
memperoleh data secara mendalam daripartisipan tentang kesulitan siswa dalam menyelesaikan masalah matematis

\section{HASIL DAN PEMBAHASAN}

Data tes memberi gambaran kemampuan dan kesulitan siswa dalam menyelesaikan masalah dari setiap langkah penyelesaian sesuai indikatoryang telah ditetapkan. Keterangan siswa pada Interview baik yang berkaitan dengan kemampuan dan kesulitan siswa dalam menyelesaikan masalah matematis digunakan sebagai data analisis dalam menggali informasi lebih dalam mengenai kemampuan dan kesulitan-kesulitan siswa dalam menyelesaikan masalah matematis dalam tes. Data observasi, catatan lapangan, dan studi dokumentasi dalam penelitian digunakan dalam menguatkan data yang ditemukan dalam tes, kuesioner, dan interview. Dalam tes pemecahan masalah, soal tes terbagi dalam dua bentuk yaitu pilihan ganda dan uraian. Hasil tes pilihan ganda digunakan dalam mendiagnosa kesulitankesulitan siswa dalam pemecahan masalah.

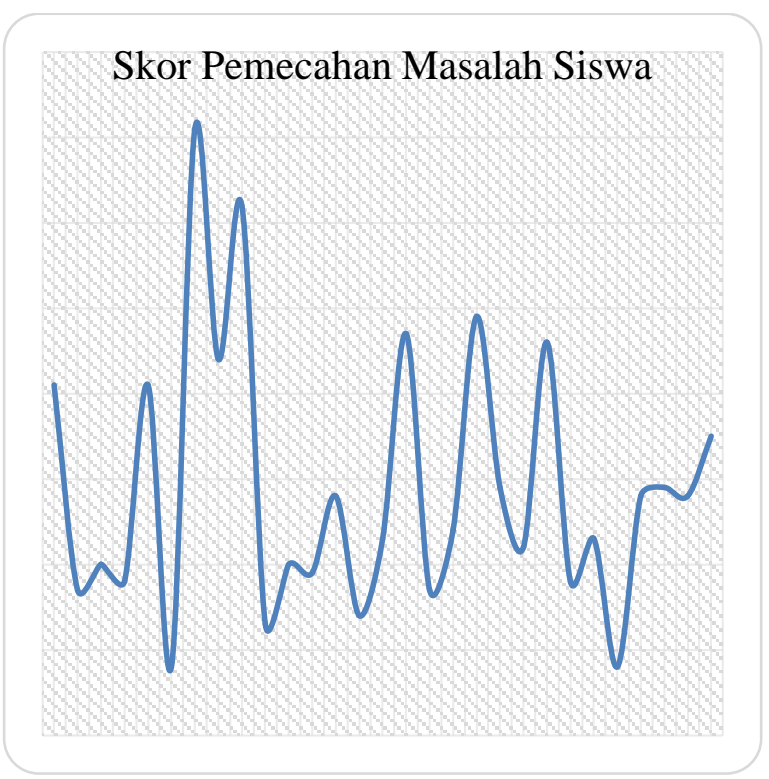

Gambar 1. Diagram Pencar Nilai Hasil Tes Pemecahan Masalah Siswa

Dari gambar di atas dapat diketahui bahwa nilai tertinggi yang diperoleh siswa adalah 71 dan nilai terendah yang diperoleh adalah 8. Dari hasil tes uraian menunjukkan bahwa sebagian besar siswa masih kesulitan dalam menyelesaikan masalah matematis.
Berikut diagram pemetaan hasil tes uraian siswa dalam pemecahan masalah:

Hasil Pemetaan Jawaban Siswa

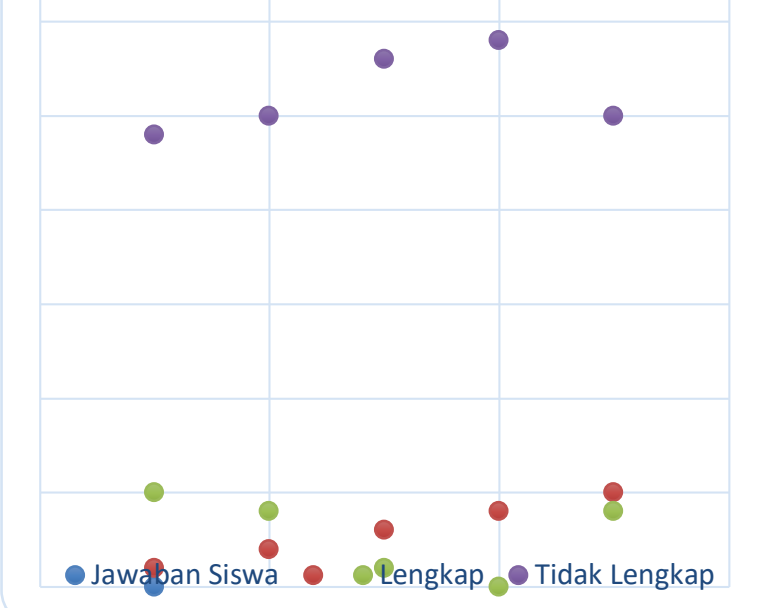

Gambar 2.Hasil Tes Pemetaan Jawaban Siswa

Berdasarkan gambar di atas dapat diketahui bahwa dari 29 siswa dalam menyelesaikan 5 butir soaluraian dalam tes pemecahan masalah. Soal nomor 1, 5 siswa yang dapat menjawab dengan lengkap. Kelima siswa itu adalah $I P, K A, R T, S F A$, dan $W M J$. Soal nomor 2, 4 siswa yang dapat menjawab dengan lengkap. Keempat siswa tersebut adalah $I P, K A, R T$, dan SFA. Soal nomor 3, hanya 1 siswa yang dapat menjawab dengan lengkap. Siswa tersebut adalah $K A$. Soal nomor 4, tidak ada siswa yang dapat menjawab dengan lengkap. Namun, soal nomor 4 hanya ada satu siswa yang dapat menyelesaikan soal dengan benar meskipun terdapat kekurangan informasi yang disebutkan pada saat menuliskan data yang diketahui dan data yang ditanyakan. Siswa tersebut adalah FYP. Adapun soal nomor 5, ada 4 siswa yang dapat menjawab dengan lengkap. Keempat siswa tersebut adalah $F Y P$, $K A, R T$, dan $S F A$. Hal ini berarti bahwa masih banyak siswa yang tidak dapat menjawab soal pemecahan masalah matematis dengan lengkap dan benar. Gambaran hasil tes pilihan ganda pemecahan masalah matematis yang diberikan kepada siswa kelas VIII selaku partisipan dalam mendiagnosa kesulitankesulitan siswa dalam memecahkan masalah matematis dapat dilihat pada gambar di bawah ini: 


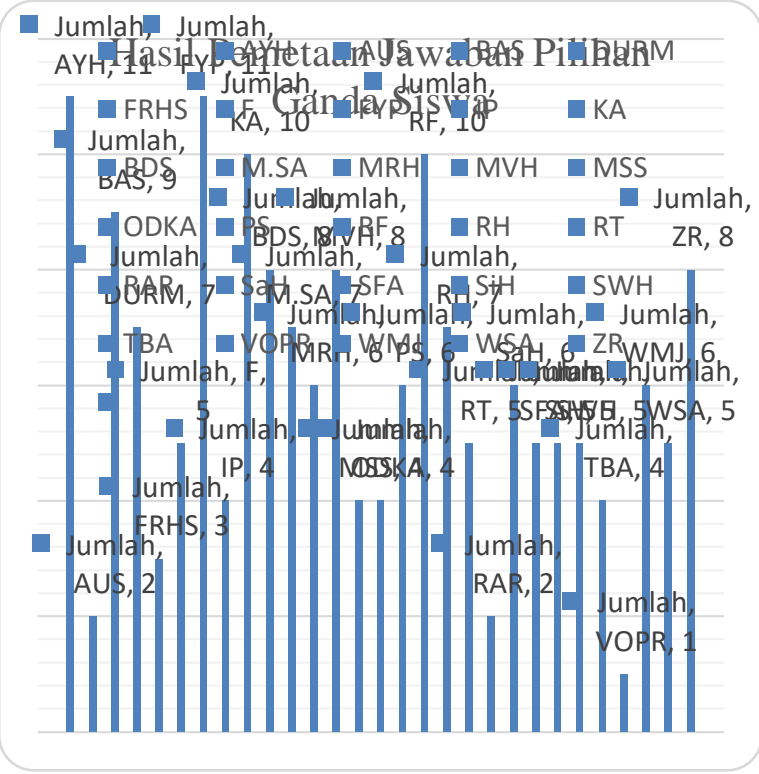

Gambar 3. Hasil Pemetaan Jawaban Pilihan Ganda Siswa

Dari hasil studi dokumentasi dapat diketahui bahwa $70 \%$ siswa mengalami kesulitan dalam bahasa, $27 \%$ siswa mengalami kesulitan dalam pemodelan, dan $40 \%$ siswa mengalami kesulitan dalam terapan. Berdasarkan interview, observasi, dan catatan lapangan yang dilakukan peneliti terhadap siswa dan guru ditemukan beberapa kesulitan siswa dalam menyelesaikan masalah matematis, di antaranya yaitu:

a. Siswa kesulitan dalam aspek bahasa sehingga siswa tidak dapat memahami, mengidentifikasi, dan menafsirkan masalah yang dihadapi.

b. Siswa kesulitan dalam aspek pemodelan sehingga siswa tidak dapat membuat representasi matematis yang jelas dan benar berdasarkan masalah baik dalam bentuk model maupun kalimat matematis lainnya.

c. Siswa kesulitan dalam aspek konsep sehingga siswa tidak dapat membuat atau memunculkan strategi baru dalam menyelesaikan masalah.

d. Siswa kesulitan dalam aspek terapan sehingga siswa tidak mampu membuat dan menjalankan strategi yang sesuai dengan masalah.

\section{REKOMENDASI}

Beberapa rekomendasi bagi siswa, guru, dan peneliti selanjutnya sebagai berikut:
1. Untuk siswa, hasil studi ini sebagai bahan refleksi dalam meningkatkan kemampuan diri dalam menyelesaikan soal pemecahan masalah matematis.

2. Untuk guru, hasil penelitian ini bisa dijadikan sebagai masukan yang positif bagi guru dalam membantu siswa dalam meningkatkan penguasaan materi prasyarat, konsep, dan skill matematis siswa dalam menyelesaikan masalah matematis

3. Peneliti selanjutnya, hasil penelitian ini bisa dijadikan sebagai referensi dan masukan dalam melakukan penelitian lanjutan baik yang berkaitan dengan pemecahan masalah siswa dalam pembelajaran. Selain itu, peneliti selanjutnya dapat mencoba metodelogi penelitian yang berbeda dalam menggali informasi kemampuan dan kesulitan siswa dalam menyelesaikan masalah matematis.

\section{KESIMPULAN}

Berdasarkan hasil dan pembahasan dalam penelitian dapat disimpulkan sebagai berikut:

1. Siswa tidak dapat membuat alternatif penyelesaian masalah yang sedang dihadapi.

2. Siswa dapat merencanakan dan membuat strategi penyelesaian dari setiap masalah yang disajikan namun siswatidak mampu menjalankan strategi penyelesaian yang telah direncanakannya.

3. Sebagian besar siswa tidak melakukan verifikasi dalam setiap langkah penyelesaian dengan baik dan benar.

4. Siswa kesulitan dalam aspek bahasa, konsep, dan terapan.

\section{DAFTAR PUSTAKA}

Angateeah, Khemduth, S. (2017). AnInvestigation of Students' Difficulties in Solving Non-Routine Word Problem at Lower Secondary. International Journal of Learning and Teaching Vol. 3, No. 1, March 2017.

Csapó, B. and J. Funke. (2017). The Nature of Problem Solving: Using Researchto Inspire 21st Century Learning. Paris: OECD Publishing. 
Delacruz, Jes Kier B. \& Lapinid, Minie Rose C. (2014). Students' Difficulties In Translating Worded Problems into Mathematical Symbols. Presented at the DLSU Research Congress 2014. De La Salle University, Manila, Philippines, March 6-8, 2014.

Herman, T. (2007). Pembelajaran Berbasis Masalah untuk Meningkatkan Kemampuan Berpikir Matematis Tingkat Tinggi Siswa Sekolah Menengah Pertama. Educationist, No.I, Vol I, Januari 2007, ISSN : 1907 - 8838.

Jaenuri, M \& Riyadi, S. (2017). Eksperimentasi Model Sinektik Terhadap Kemampuan Pemecahan Masalah Matematis dan Self Efficacy Siswa. Edumatica Volume 07, Nomor 02, Oktober 2017, ISSN: 2088-2157.

Jupri, A \& Drijvers, P. (2016). Student Difficulties in Mathematizing Word Problems in Algebra.Eurasia Journal of Mathematics, Science \& Technology Education, 2016, 12(9).

Komarudin. (2016). Analisis Kesalahan Siswa dalam Pemecahan Masalah Matematis pada Materi PeluangBerdasarkan High Order Thinking dan Pemberian Scaffolding. Jurnal Pendidikan, Komunikasi dan Pemikiran Hukum Islam, Volume VIII, No.1, 198-213, September 2016, ISSN: 1978-4767.

Krulik, Stephen dan Rudnick, Jesse A. (1995). The New Sourcebook for Teaching Reasoning and Problem Solving in Elementary School. Boston:Temple University.

Mullis, I.V.S., Martin, M.O., Gonzales, E.J., Gregory, K.D., Garden, R.A., O'Connor, K.M., Krostowski, S.J., \& Smith, T.A. 2000. TIMSS 1999: International Mathematics Report. Boston: ISC.

NCTM. (2000). Principles and Standards for School Mathematics. Reston, VA: Author.

Polya, G. (1973). How to solve It. New Jersey: Princeton University Press.

Salemeh, Z \& Etchells, M. J. (2016). A Case Study: Sources of Difficulties in Solving Word Problems in an International
Private School. EIJEAS (Electronic International Journal of Education, Arts, and Science), Volume:2, Issue: Special Issue, 149-163.

Seifi, M., Haghverdi, M., \& Azizmohamadi, F. (2012). Recognition of Students' Difficulties in Solving Mathematical Word Problems from the Viewpoint of Teachers. Journal of Basic and Applied Scientific Research (J. Basic Appl. Sci. Res), 2(3), 2923-2928, ISSN 2090-4304.

Sholihah, S. Z \& Afriansyah, E. A. (2017). Students' Difficulties Analysis in Problem Solving Process of Geometry Based on Van Hiele Thinking Stages. Jurnal Mosharafa, Volume 6, Nomor 2, Mei 2017.

Syahlan. (2017). Sepuluh Strategi dalam Pemecahan Masalah Matematis. Indonesian Digital Journal of Mathematics and Education (IDJME), Volume 4 Nomor 6 Tahun 2017, http://idealmathedu.p4tkmatematis.org ISSN 2407-8530. 